\title{
Residual Ferrite Control of 9Cr ODS Steels by Tailoring Reverse Austenite Transformation
}

\author{
Xiaosheng Zhou ${ }^{1} \cdot$ Hao Chen ${ }^{1}$. Chenxi Liu ${ }^{2}$ Yongchang Liu ${ }^{2}$
}

Received: 30 July 2020 / Revised: 16 September 2020 / Accepted: 27 September 2020 / Published online: 3 January 2021

(c) The Chinese Society for Metals (CSM) and Springer-Verlag GmbH Germany, part of Springer Nature 2021

\begin{abstract}
By tailoring the reverse austenite transformation behavior of $9 \mathrm{Cr}$ oxide dispersion strengthened (ODS) ferritic/martensitic steels, the residual ferrite in ODS steels can be controlled. The reverse austenite transformation behavior of ODS steels is closely related to the initial microstructure conditions prior to austenite transformation. For the spark plasma sintered steels, both the amount and size of residual ferrite decrease with increasing heating rate. Nevertheless, high heating rate will increase the amount and size of residual ferrite in annealed ODS steels. As an isothermal treatment is performed at temperatures above $\mathrm{Ac}_{1}$, lower isothermal temperature has a more evident effect on the ferrite distribution in spark plasma sintered steels than that in annealed ones.
\end{abstract}

Keywords Oxide dispersion strengthened steels $\cdot$ Residual ferrite $\cdot$ Austenite transformation

\section{Introduction}

Oxide dispersion strengthened (ODS) ferritic/martensitic steels have been considered as one promising candidate material for first walls in fusion nuclear reactors, owing to their advantages in low radiation resistance and good hightemperature performance $[1,2]$. Due to the high melting point of oxide nanoparticles, the ODS steels are generally fabricated by mechanically alloying, followed by hot consolidation [3-5]. Considering the difference in alloy compositions and microstructure characteristics, the ODS ferritic/martensitic steels can be classified into ODS ferritic steels and ODS martensitic steels [6-9]. Although ODS ferritic steels with high chromium content exhibit higher oxidation resistance and creep strength, the ODS martensitic steels have better workability $[10,11]$. The austenite

Available online at http://link.springer.com/journal/40195.

Yongchang Liu

licmtju@163.com

1 Key Laboratory for Advanced Materials of Ministry of Education, School of Materials Science and Engineering, Tsinghua University, Beijing 100084, China

2 State Key Lab of Hydraulic Engineering Simulation and Safety, School of Materials Science and Engineering, Tianjin University, Tianjin 300354, China transformation in ODS martensitic steels is beneficial to reduce the inhomogeneity and anisotropy in microstructure and mechanical properties [12].

As the pinning force exerted by oxide nanoparticles on ferrite/austenite interface overwhelms the driving force of austenitic transformation, the ferrite cannot be completely transformed to austenite, leaving a certain amount of untransformed ferrite in the matrix, namely residual ferrite $[13,14]$. The residual ferrite is produced in heating stage of ODS steels, which is quite different from the transformed ferrite produced in cooling stage. The residual ferrite is characteristics of high density of oxide nanoparticles, exhibiting higher hardness than the tempered martensite. It can improve the creep strength of 9Cr ODS steels by combining the soft tempered martensite and hard residual ferrite [15]. A small amount of residual ferrite can induce easy deformation of the soft tempered martensite, while large volumes of residual ferrite tend to induce stress concentration and lead to cracks at the soft/hard interface $[16,17]$. Therefore, it is essential to optimize the distribution of residual ferrite in ODS steels.

The increase in carbon and nitrogen contents could increase the driving force for austenitic transformation, decreasing the amount of residual ferrite [18-20]. Excess oxygen concentration (the value obtained by subtracting oxygen concentration coupled with yttrium in $\mathrm{Y}_{2} \mathrm{O}_{3}$ from total oxygen concentration in steel) also has a significant 
effect on ferrite formation. It was found that as the excess oxygen was $0.08 \mathrm{wt} \%$, the $9 \mathrm{Cr}$ ODS steels with $0.2 \mathrm{wt} \%$ Ti had the most residual ferrite [21]. Except for alloying elements, the thermo-mechanical treatments might result in the reduction of the total number density of nanosized particles, decreasing the volume fraction of residual ferrite phase [22]. In this work, by changing the driving force of austenite transformation, the dependency of residual ferrite on the specimen conditions, heating rate and isothermal treatment is discussed.

\section{Experimental}

Inert-gas-atomized powder with nominal composition of $\mathrm{Fe}-9 \mathrm{Cr}-0.1 \mathrm{C}-2 \mathrm{~W}-0.2 \mathrm{~V}-0.07 \mathrm{Ta}$ (in wt $\%$ ) was blended with $0.35 \mathrm{wt} \% \mathrm{Y}_{2} \mathrm{O}_{3}$ in stainless cans and then mechanically milled for $45 \mathrm{~h}$ in a planetary ball mill, with argon atmosphere as the protection. The rotation speed was $400 \mathrm{rpm}$, and the ball-to-powder ratio was 15:1. By spark plasma sintering (SPS) machine, milled powder was consolidated in a graphite die with $20 \mathrm{~mm}$ inner diameter. The powder was first heated to $800{ }^{\circ} \mathrm{C}$ for $5 \mathrm{~min}$ at a $\sim 100 \mathrm{~K} / \mathrm{min}$ and then continuously heated to $1100{ }^{\circ} \mathrm{C}$ for $10 \mathrm{~min}$, followed by the continuous cooling in spark plasma furnace. An axial pressure of $40 \mathrm{MPa}$ had been applied throughout the heating stage. To avoid the carbon contamination from graphite die in SPS, the samples were machined from the position $2 \mathrm{~mm}$ away from the top of the sintered sample. The spark plasma sintered samples were annealed at $800{ }^{\circ} \mathrm{C}$ for $1 \mathrm{~h}$.

Thermal measurements of as-sintered and as-annealed ODS samples were taken on a differential scanning calorimeter (DSC)/thermo gravimetric analyzer. The samples were heated to $1100{ }^{\circ} \mathrm{C}$ with four different rates $\left(10^{\circ} \mathrm{C} /\right.$ min, $20^{\circ} \mathrm{C} / \mathrm{min}, 30^{\circ} \mathrm{C} / \mathrm{min}$ and $40{ }^{\circ} \mathrm{C} / \mathrm{min}$, respectively) and held at this temperature for $5 \mathrm{~min}$ and then cooled to room

\section{(1) Continuous Heating}

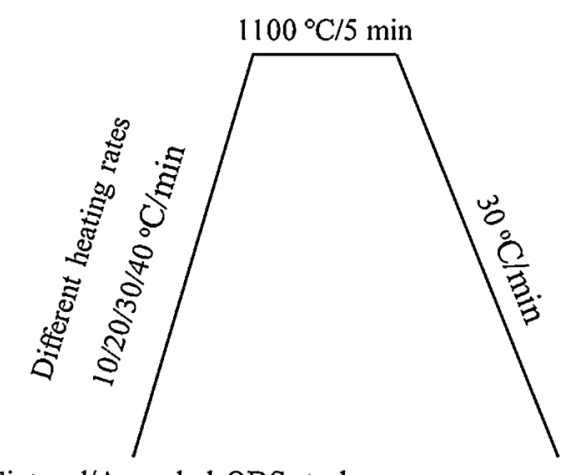

Sintered/Annealed ODS steels temperature at $30^{\circ} \mathrm{C} / \mathrm{min}$. DSC curves displayed here are the subtraction results of the measured curves to the baselines, and the "spline" baseline mode was adopted. Isothermal treatment in austenitic region to control the ferrite in $9 \mathrm{Cr}$ ODS steels is as follows: As-sintered or as-annealed samples were heated to $870{ }^{\circ} \mathrm{C}$ or $1000{ }^{\circ} \mathrm{C}$ for $10 \mathrm{~min}$ at $40^{\circ} \mathrm{C} / \mathrm{min}$ and then continuously heated to $1100^{\circ} \mathrm{C}$ for $5 \mathrm{~min}$ at $40^{\circ} \mathrm{C} /$ min, followed by cooling to room temperature at $30^{\circ} \mathrm{C} / \mathrm{min}$. A sketch map showing the heat treatments of $9 \mathrm{Cr}$ ODS steels is shown in Fig. 1.

Microstructures of as-sintered and as-annealed bulks were analyzed through an optical microscope (OM), a scanning electron microscope (SEM) and a transmission electron microscope (TEM). For OM and SEM examination, metallographic specimens were etched in a mixed solution of water $(100 \mathrm{~mL})$, hydrochloric acid $(20 \mathrm{~mL})$ and iron trichloride $(5 \mathrm{~g})$. TEM disks were prepared in a solution of $5 \mathrm{vol} \%$ perchloric acid in ethanol by twin-jet-polishing.

\section{Results}

\subsection{Continuous Heating}

\subsubsection{Sintered Condition}

Figure 2 shows the DSC curves of the as-sintered 9Cr ODS steels upon heating with different heating rates. At each heating rate, there exists one exothermic peak in the temperature range from 600 to $700{ }^{\circ} \mathrm{C}$, which can be ascribed to the crystallization of $\mathrm{Y}_{2} \mathrm{O}_{3}$ with amorphous structure or the growth of $\mathrm{Y}_{2} \mathrm{O}_{3}$ nanocrystalline [23]. The first endothermic peak in heating relates to the Curie transition, and the second one is related to austenite transformation. The austenite start temperature $\left(\mathrm{Ac}_{1}\right)$ and finish temperature $\left(\mathrm{Ac}_{3}\right)$ of the sintered ODS steel under each heating rate are indicated in
(2) Isothermal Treatment

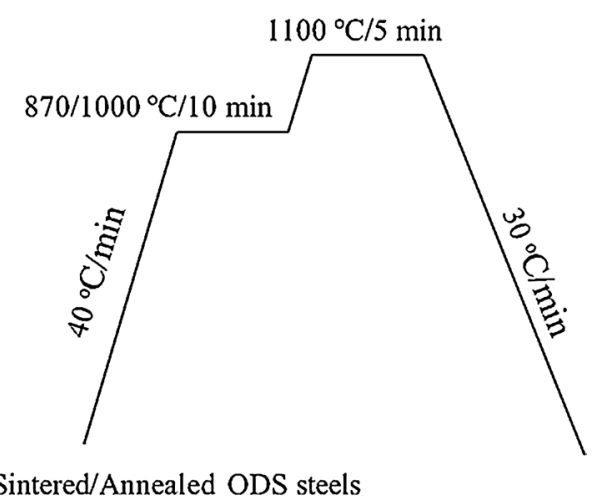

Sintered/Annealed ODS steels

Fig. 1 Sketch map showing the heat treatments of 9Cr ODS steels 


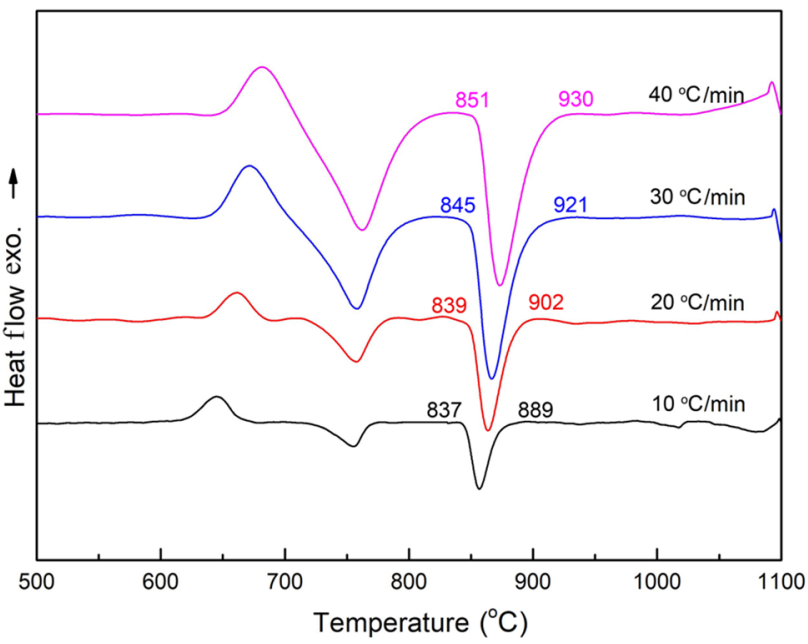

Fig. 2 DSC curves of as-sintered 9Cr-ODS steels under various heating rates

Fig. 2. With increasing heating rate, both $\mathrm{Ac}_{1}$ and $\mathrm{Ac}_{3}$ shift to high temperature regime. The enthalpy of austenite transformation at each heating rate is, respectively, calculated as $-5.5 \mathrm{~J} / \mathrm{g}$ at $10{ }^{\circ} \mathrm{C} / \mathrm{min},-6.0 \mathrm{~J} / \mathrm{g}$ at $20^{\circ} \mathrm{C} / \mathrm{min},-7.6 \mathrm{~J} / \mathrm{g}$ at $30{ }^{\circ} \mathrm{C} / \mathrm{min}$ and $-7.7 \mathrm{~J} / \mathrm{g}$ at $-40{ }^{\circ} \mathrm{C} / \mathrm{min}$. There is an increasing tendency for the transformation enthalpy as the heating rate increases. The larger austenite transformation enthalpy at faster heating rate indicates that more austenite is produced.

Figure 3 shows the OM images of as-sintered 9Cr-ODS steels with different heating rates. Heating rate has a significant effect on the microstructure of sintered ODS steels. After DSC thermal cycle, the microstructure consists of martensite (dark region) and ferrite (bright region). Ferrite is distributed homogeneously within the matrix, yet both fraction and size of ferrite vary with the heating rate. Quantitative analysis results of ferrite are summarized in Fig. 4. Both the amount and grain size of ferrite decrease with increasing heating rate. As the heating rate increases from 10 to $40{ }^{\circ} \mathrm{C} /$ min, the average amount of ferrite decreases from $9.2 \%$ to $3.8 \%$, and the mean grain size decreases from 5.7 to $2 \mu \mathrm{m}$. To clarify the distribution of oxide nanoparticles in martensite and ferrite, TEM examination was performed. Figure 5 shows the TEM images of the martensite and ferrite in the ODS steel heated at $10{ }^{\circ} \mathrm{C} / \mathrm{min}$. In Fig. 5a, the interface between martensite and ferrite is clean, and no large-sized carbides could be found. Figure 5b, c, respectively, shows
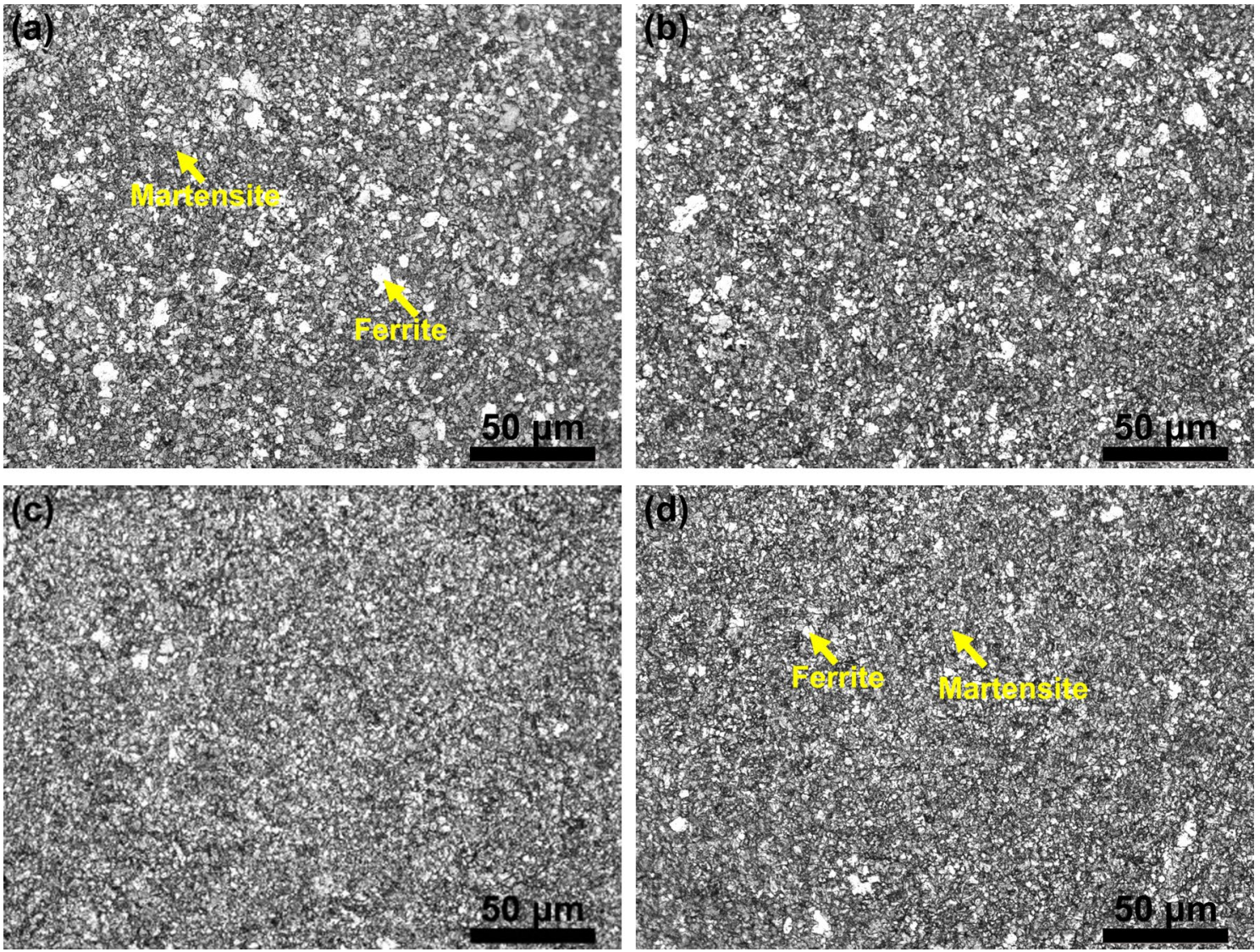

Fig. $3 \mathrm{OM}$ micrographs of as-sintered $9 \mathrm{Cr}$-ODS steels under different heating rates: a $10{ }^{\circ} \mathrm{C} / \mathrm{min}, \mathbf{b} 20{ }^{\circ} \mathrm{C} / \mathrm{min}, \mathbf{c} 30^{\circ} \mathrm{C} / \mathrm{min}, \mathbf{d ~} 40{ }^{\circ} \mathrm{C} / \mathrm{min}$ 


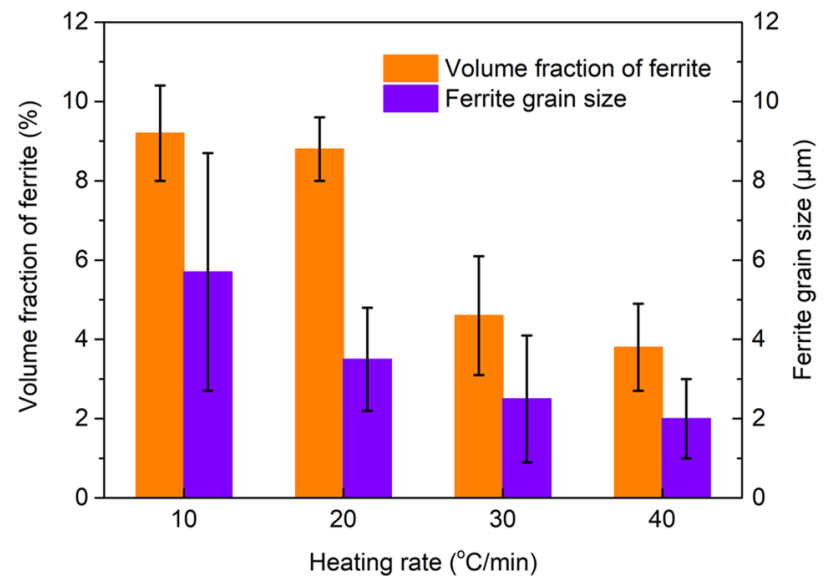

Fig. 4 Volume fraction and grain size of ferrite in as-sintered $9 \mathrm{Cr}-$ ODS steels subjected to various heating rates

the oxide nanoparticles in martensite and ferrite. The oxide nanoparticles in ferrite exhibit higher density and smaller size than those in martensite. This is consistent with the oxide distribution characteristics in residual ferrite. On the other hand, certain amount of dislocation can also be found in ferrite, as shown in Fig. 5c. Dislocations are bowed out by the oxide particles, indicating that Orowan mechanism operates between oxide particles and dislocations. Considering the carbide absence and high density of oxides in ferrite, the ferrite should be residual ferrite, rather than transformed ferrite.

\subsubsection{Annealed Condition}

DSC curves of the as-annealed 9Cr ODS steels upon heating with different heating rates are shown in Fig. 6. For the annealed ODS steels, no exothermic peak appears in heating. Both $A c_{1}$ and $A c_{3}$ under various heating rates are indicated in Fig. 6. At each heating rate, there is no significant difference between the sintered steels and anneal ones in austenite

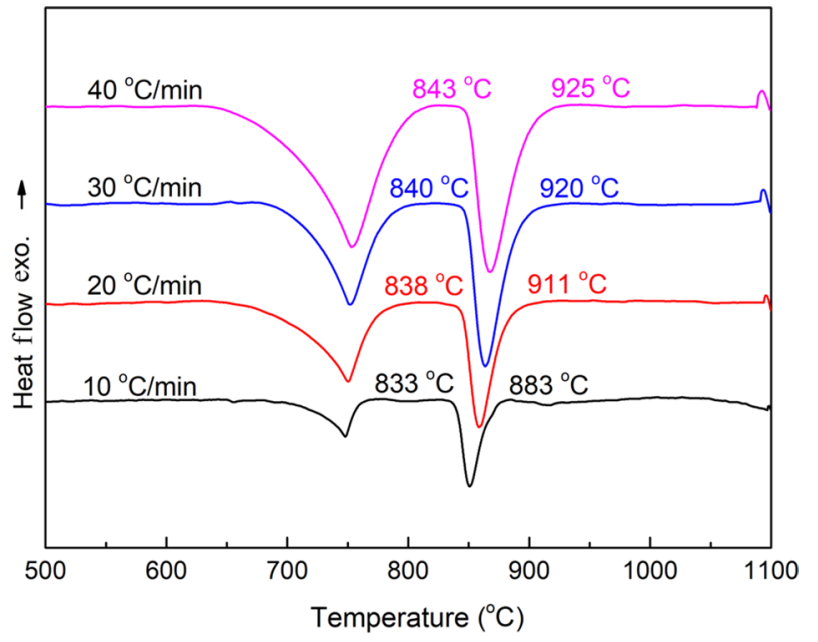

Fig. 6 Under different heating rates, DSC curves of as-annealed 9CrODS steels in heating

start and finish temperatures. It seems that the thermodynamics of austenite transformation is affected slightly by the initial condition of ODS steels. The enthalpy of austenite transformation at each heating rate is, respectively, calculated as $-7.9 \mathrm{~J} / \mathrm{g}$ at $10{ }^{\circ} \mathrm{C} / \mathrm{min},-6.7 \mathrm{~J} / \mathrm{g}$ at $20{ }^{\circ} \mathrm{C} /$ $\min ,-6.6 \mathrm{~J} / \mathrm{g}$ at $30{ }^{\circ} \mathrm{C} / \mathrm{min}$ and $-6.6 \mathrm{~J} / \mathrm{g}$ at $-40^{\circ} \mathrm{C} / \mathrm{min}$. Different from the sintered ODS steel, there is an decreasing tendency for the transformation enthalpy as the heating rate increases, although the transformation enthalpies at $20{ }^{\circ} \mathrm{C} /$ min, $30^{\circ} \mathrm{C} / \mathrm{min}$ and $40{ }^{\circ} \mathrm{C} / \mathrm{min}$ are quite close. The larger austenite transformation enthalpy at slower heating rate indicates that more austenite is produced.

Figure 7 shows the OM micrographs of the annealed $9 \mathrm{Cr}$ ODS steel after DSC thermal cycle. At each heating rate, the microstructure also consists of martensite and ferrite, and the ferrite distribution is also related to the heating rate. Figure 8 shows the dependency of ferrite amount and size
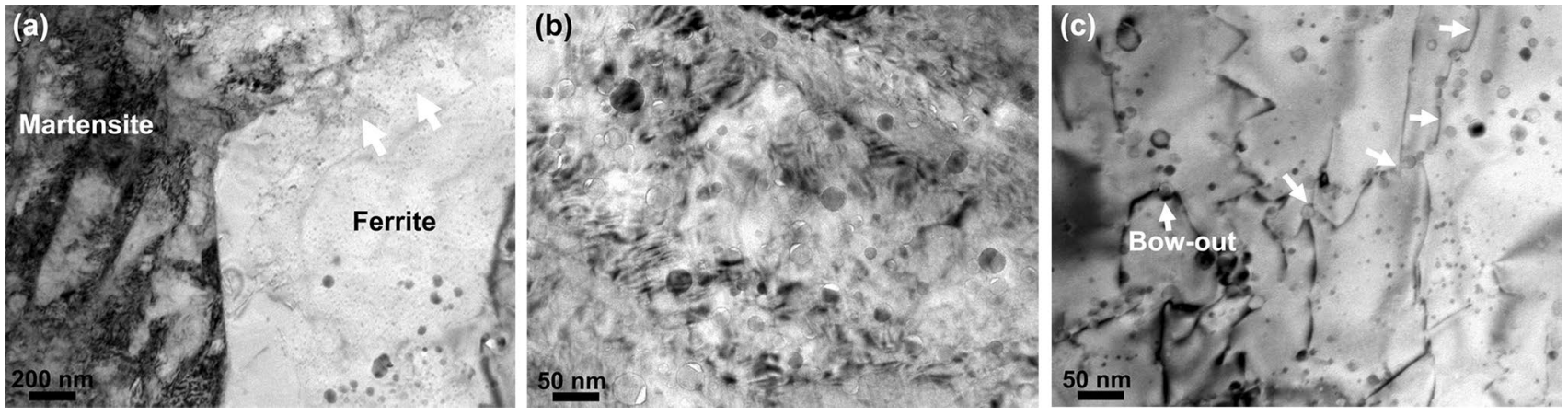

Fig. 5 a Martensite/ferrite interphase boundary in 9Cr-ODS steel under heating rate of $10{ }^{\circ} \mathrm{C} / \mathrm{min}$, the oxide distribution in $\mathbf{b}$ martensite, $\mathbf{c}$ ferrite 

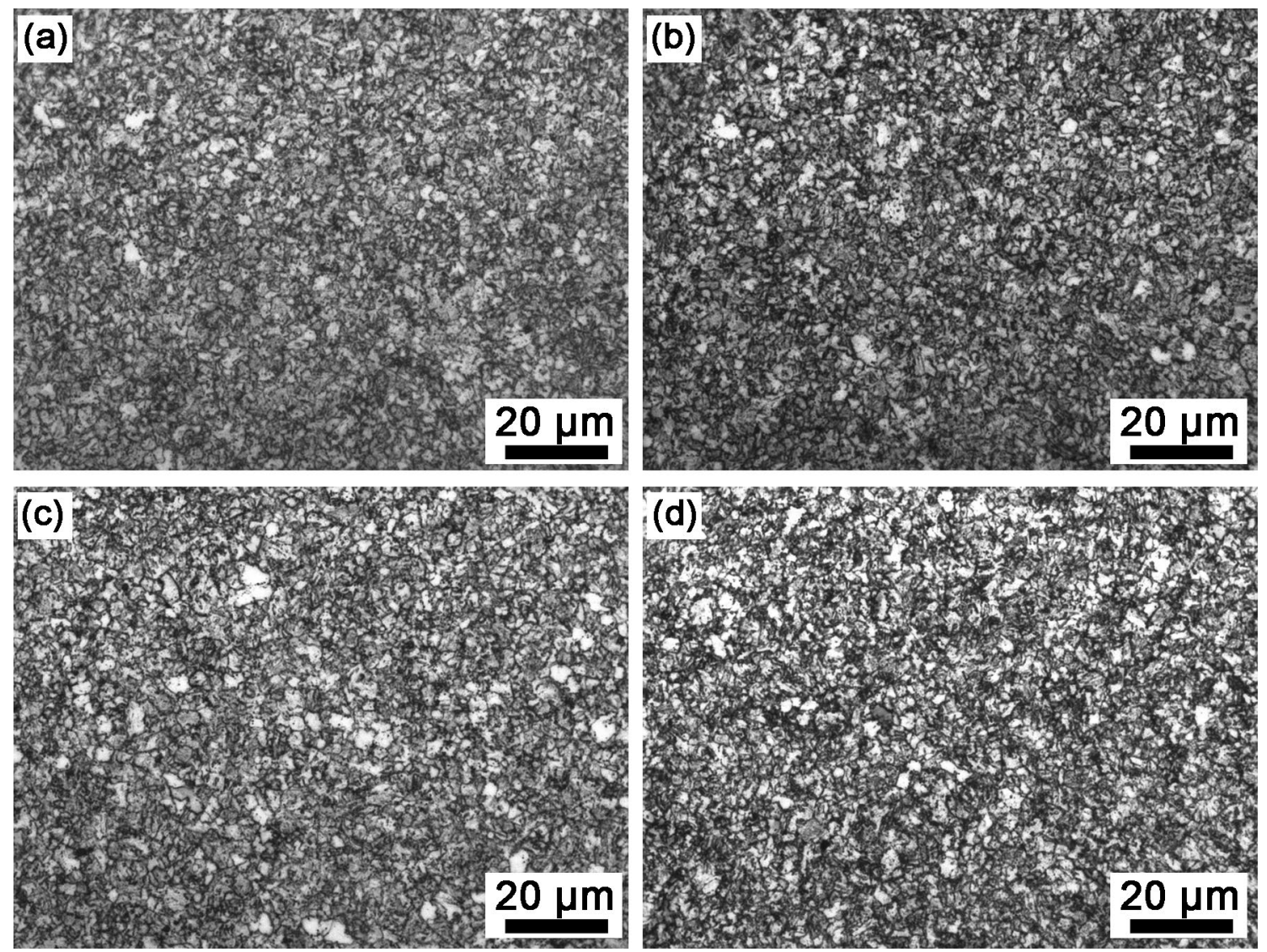

Fig. 7 OM micrographs of as-annealed $9 \mathrm{Cr}$-ODS steels under different heating rates: a $10{ }^{\circ} \mathrm{C} / \mathrm{min}, \mathbf{b} 20{ }^{\circ} \mathrm{C} / \mathrm{min}, \mathbf{c} 30^{\circ} \mathrm{C} / \mathrm{min}, \mathbf{d ~} 40^{\circ} \mathrm{C} / \mathrm{min}$

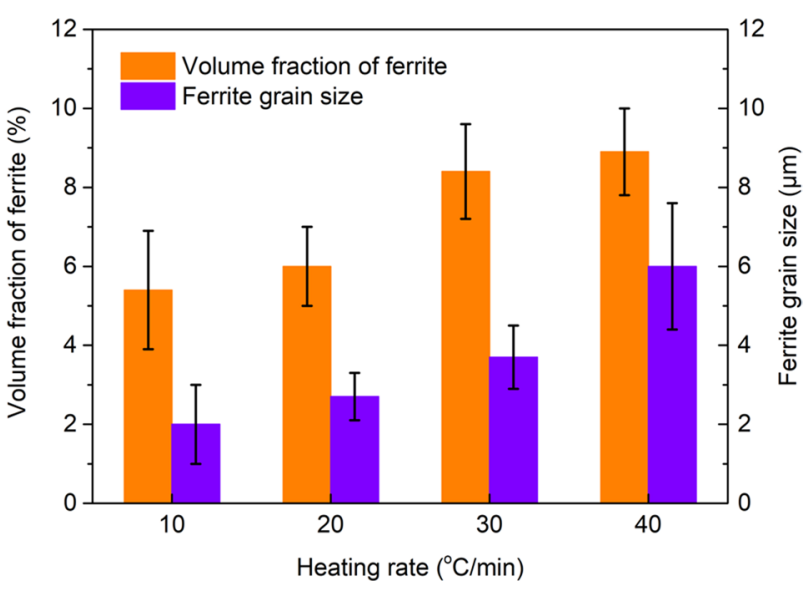

Fig. 8 Volume fraction and size of ferrite in as-annealed 9Cr-ODS steels subjected to various heating rates

on heating rate. Contrast with the sintered ODS steel, as the heating rate increases, both the amount of the amount and grain size of ferrite increases with increasing heating rate. As the heating rate increases from 10 to $40{ }^{\circ} \mathrm{C} / \mathrm{min}$, the average amount of ferrite increases from 5.4 to $8.9 \%$, and the mean grain size increases from 2 to $6 \mu \mathrm{m}$. The heating rate has an opposite effect on the variation in the amounts and sizes of ferrite. Actually, the annealed 9Cr ODS steel has quite different microstructure characteristics from the sintered ODS steel, and the detailed microstructure characterization can be referred to the Ref. [23]. The sintered steel is characteristics of martensite with supersaturated carbon and high density of dislocations, while the annealed steel is tempered martensite with $M_{23} \mathrm{C}_{6}$ precipitation and low density of dislocations. Under each condition, the $\mathrm{Y}_{2} \mathrm{O}_{3}$ size exhibits normal distribution, and the average particle size of $\mathrm{Y}_{2} \mathrm{O}_{3}$ particles in as-sintered steel and as-annealed steel is, respectively, determined as $9.2 \mathrm{~nm}$ and $12 \mathrm{~nm}$. The changes in the initial microstructure lead to the different response of the ferrite distribution to the heating rate. Figure 9 shows the TEM images of the annealed ODS steels heated at $10{ }^{\circ} \mathrm{C} /$ min and $40^{\circ} \mathrm{C} / \mathrm{min}$. Heating rate has a negligible effect on the martensite morphology. Different from the sintered ODS steel, large-sized $M_{23} \mathrm{C}_{6}$ carbides are found in the martensite, as shown in Fig. $9 \mathrm{a}$, c. For $40{ }^{\circ} \mathrm{C} / \mathrm{min}$, more $M_{23} \mathrm{C}_{6}$ carbides are readily revealed, as indicated by arrows. Figure $9 \mathrm{~b}, \mathrm{~d}$ shows the martensite/ferrite interface in the steels heated at $10{ }^{\circ} \mathrm{C} / \mathrm{min}$ and $40{ }^{\circ} \mathrm{C} / \mathrm{min}$. Similar to the sintered ODS 

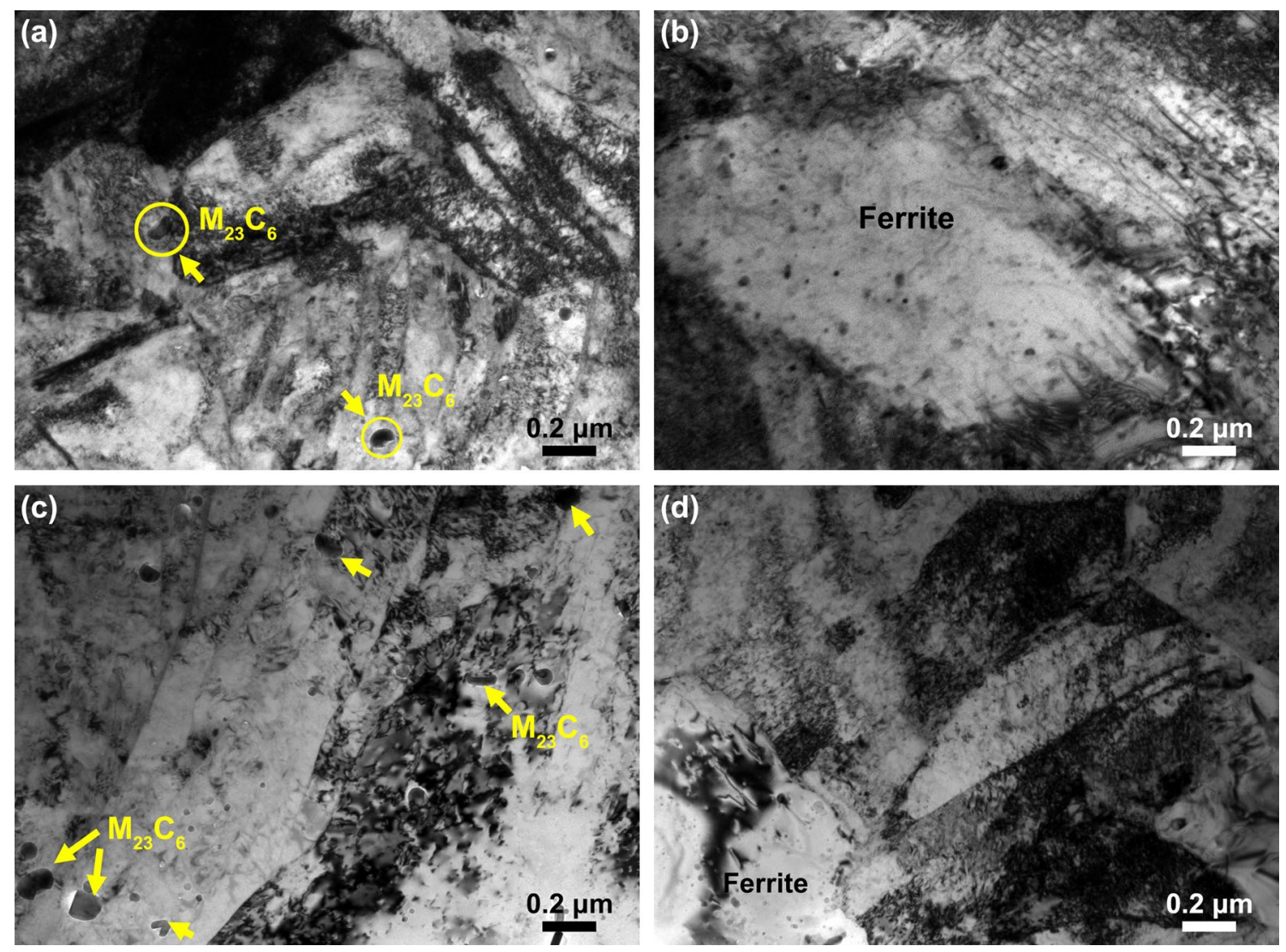

Fig. 9 TEM images showing microstructure of as-annealed $9 \mathrm{Cr}$-ODS steels subjected to heating rates of $\mathbf{a}, \mathbf{b} 10^{\circ} \mathrm{C} / \mathrm{min}, \mathbf{c}, \mathbf{d} 40^{\circ} \mathrm{C} / \mathrm{min}$

steel, the interface between martensite and ferrite is clean, and high density of fine oxide nanoparticles can be observed. The ferrite in the heat treated annealed ODS steel can also be classified into the residual ferrite.

\subsection{Isothermal Treatment}

Heating rate can affect the residual ferrite distribution in ODS steels. Considering the formation mechanism of residual ferrite, it is suggested that the heating rate actually changes the time remained in austenite region to affect the ferrite formation. Thus, isothermal treatment above $\mathrm{Ac}_{1}$ should also be able to tailor the ferrite distribution. In this part, two isothermal temperatures are selected, namely $870{ }^{\circ} \mathrm{C}$ and $1000{ }^{\circ} \mathrm{C}$. The steels were heated to $870{ }^{\circ} \mathrm{C}$ or $1000{ }^{\circ} \mathrm{C}$ for $10 \mathrm{~min}$ at $40{ }^{\circ} \mathrm{C} / \mathrm{min}$ and then still heated to $1100{ }^{\circ} \mathrm{C}$ for $5 \mathrm{~min}$ at $40{ }^{\circ} \mathrm{C} / \mathrm{min}$, followed by cooling to room temperature.

\subsubsection{Sintered Condition}

Figure 10 shows the OM and SEM images of the sintered $9 \mathrm{Cr}$ ODS steels isothermally treated at $870{ }^{\circ} \mathrm{C}$ and $1000{ }^{\circ} \mathrm{C}$, with heating rate of $40{ }^{\circ} \mathrm{C} / \mathrm{min}$. As the isothermal temperature is $870{ }^{\circ} \mathrm{C}$, the average amount of the residual ferrite is about $10 \%$, and the mean ferrite grain size is $4.6 \mu \mathrm{m}$. With respect to isothermal temperature of $1000^{\circ} \mathrm{C}$, the average amount and size of ferrite are, respectively, $4.4 \%$ and $2.5 \mu \mathrm{m}$. In Sect. 3.1.1, as-sintered 9Cr ODS steel was continuously heated to $1100{ }^{\circ} \mathrm{C}$ at $40^{\circ} \mathrm{C} / \mathrm{min}$, and the average amount and size of ferrite are, respectively, 3.8\% and $2 \mu \mathrm{m}$. By isothermal treatment above $\mathrm{Ac}_{1}$, the amount and size of ferrite in sintered ODS steel are increased. For the continuous heating at $40{ }^{\circ} \mathrm{C} / \mathrm{min}$, the $\mathrm{Ac}_{1}$ and $\mathrm{Ac}_{3}$ are, respectively, $851{ }^{\circ} \mathrm{C}$ and $930{ }^{\circ} \mathrm{C}$. This means that the $870{ }^{\circ} \mathrm{C}$ is in the range of $\mathrm{Ac}_{1}<870{ }^{\circ} \mathrm{C}<\mathrm{Ac}_{3}$, and $1000{ }^{\circ} \mathrm{C}$ is in the range of $\mathrm{Ac}_{3}<1000{ }^{\circ} \mathrm{C}$. Setting the amount and size of ferrite produced in continuous heating as the baseline (3.8\% and $2 \mu \mathrm{m}$, respectively), the increments for the amount and size of ferrite under $870{ }^{\circ} \mathrm{C}$ are larger than those under $1000^{\circ} \mathrm{C}$. This means that for the sintered $9 \mathrm{Cr}$ ODS steel, as the isothermal temperature is between $\mathrm{Ac}_{1}$ 

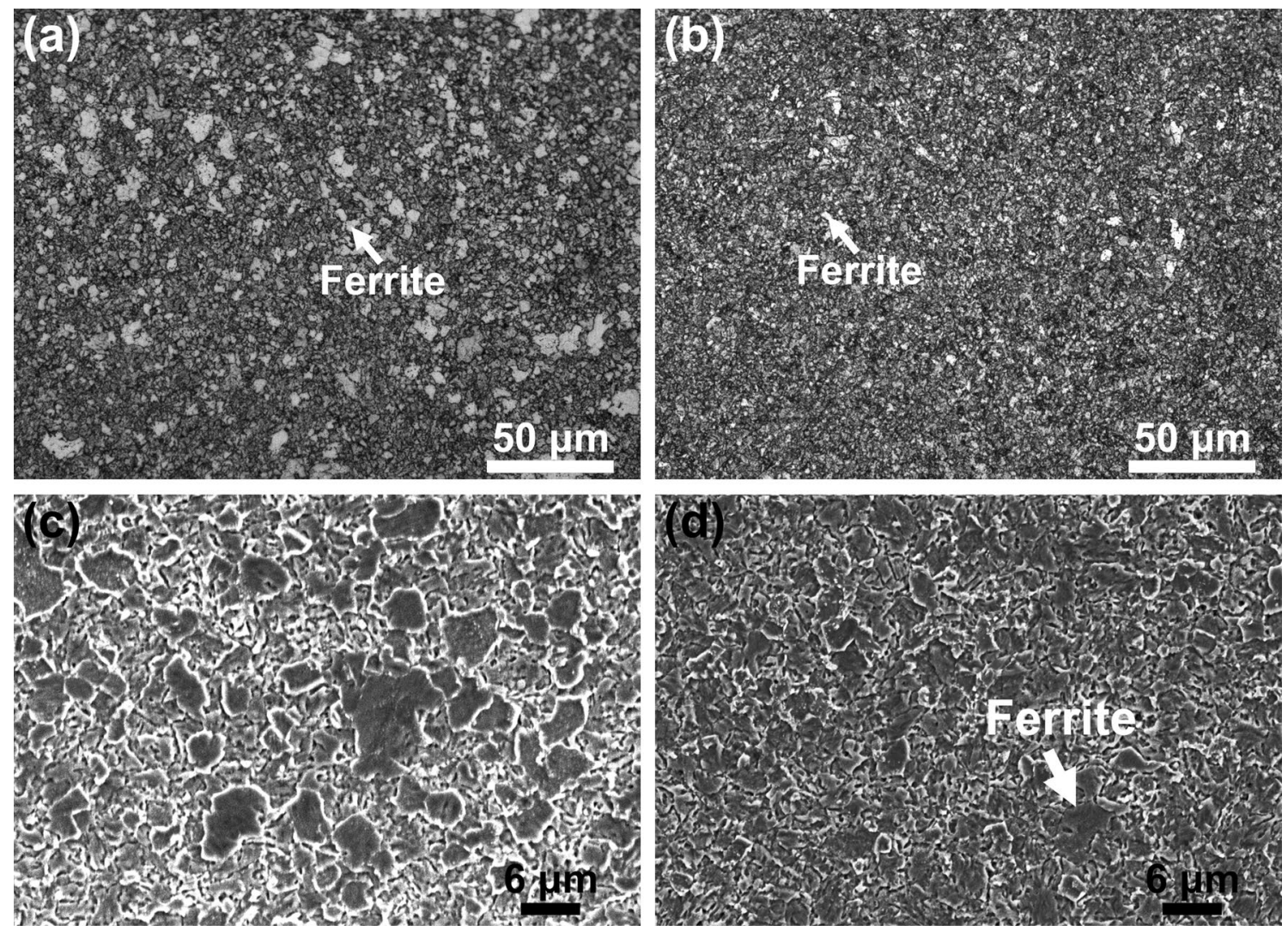

Fig. $10 \mathrm{OM}$ and SEM micrographs of as-sintered $9 \mathrm{Cr}$-ODS steels subjected to isothermal treatment at $\mathbf{a}, \mathbf{c} 870{ }^{\circ} \mathrm{C}, \mathbf{b}, \mathbf{d} 1000{ }^{\circ} \mathrm{C}$

and $\mathrm{Ac}_{3}$, the isothermal treatment has a more evident effect on the ferrite distribution.

\subsubsection{Annealed Condition}

OM and SEM images of the sintered 9Cr ODS steels isothermally treated at $870{ }^{\circ} \mathrm{C}$ and $1000^{\circ} \mathrm{C}$ are shown in Fig. 11 . As the isothermal temperature is $870{ }^{\circ} \mathrm{C}$, the average amount of the residual ferrite is about $7.4 \%$, and the mean ferrite grain size is $3 \mu \mathrm{m}$. Under isothermal temperature of $1000^{\circ} \mathrm{C}$, the average amount and size of ferrite are, respectively, $6.5 \%$ and $2.7 \mu \mathrm{m}$. In Sect. 3.1.2, as-annealed 9Cr ODS steel was continuously heated to $1100{ }^{\circ} \mathrm{C}$ at $40{ }^{\circ} \mathrm{C} / \mathrm{min}$, and the average amount and size of ferrite are, respectively, $8.9 \%$ and $6 \mu \mathrm{m}$. For the continuous heating at $40^{\circ} \mathrm{C} / \mathrm{min}$, the $\mathrm{Ac}_{1}$ and $\mathrm{Ac}_{3}$ are, respectively, $843{ }^{\circ} \mathrm{C}$ and $925^{\circ} \mathrm{C}$. Comparing with the amount and size of ferrite produced in continuous heating ( $8.9 \%$ and $6 \mu \mathrm{m}$, respectively), the decrements for the amount and size of ferrite under $1000{ }^{\circ} \mathrm{C}$ are larger than those under $870{ }^{\circ} \mathrm{C}$. This means that for the annealed $9 \mathrm{Cr}$ ODS steel, as the isothermal temperature is larger than $\mathrm{Ac}_{3}$, the isothermal treatment has a more evident effect on the ferrite distribution.

\section{Discussion}

For the same heat treatment, the final distribution of ferrite is dependent on the initial microstructure of 9Cr ODS steels prior to heat treatment. Detailed characterization for the sintered and annealed 9Cr ODS steels has been performed in previous work [23]. The sintered steel was fabricated by SPS, a fast consolidation technology, and the microstructure is characteristic of martensite with high density of dislocation, indicating high strain energy. The carbon is supersaturated into the martensite. After annealing treatment, $M_{23} \mathrm{C}_{6}$ carbides are precipitated along prior austenite boundaries, lath boundaries and within grains. Dislocation recovery or recrystallization occurs, and the dislocation density is drastically decreased. The existence form of carbon, dislocation density and strain energy are quite different between the sintered and annealed steels. This will affect the driving force of austenite transformation upon subsequent heat treatment. The reverse transformation from martensite to austenite can be operated by diffusionless mechanism or diffusive mechanism. Diffusionless transformation is characteristics of lathshaped reversed austenite with a high dislocation density, while diffusive transformation is characteristics of equiaxed grains with a low dislocation density. Since the driving force 

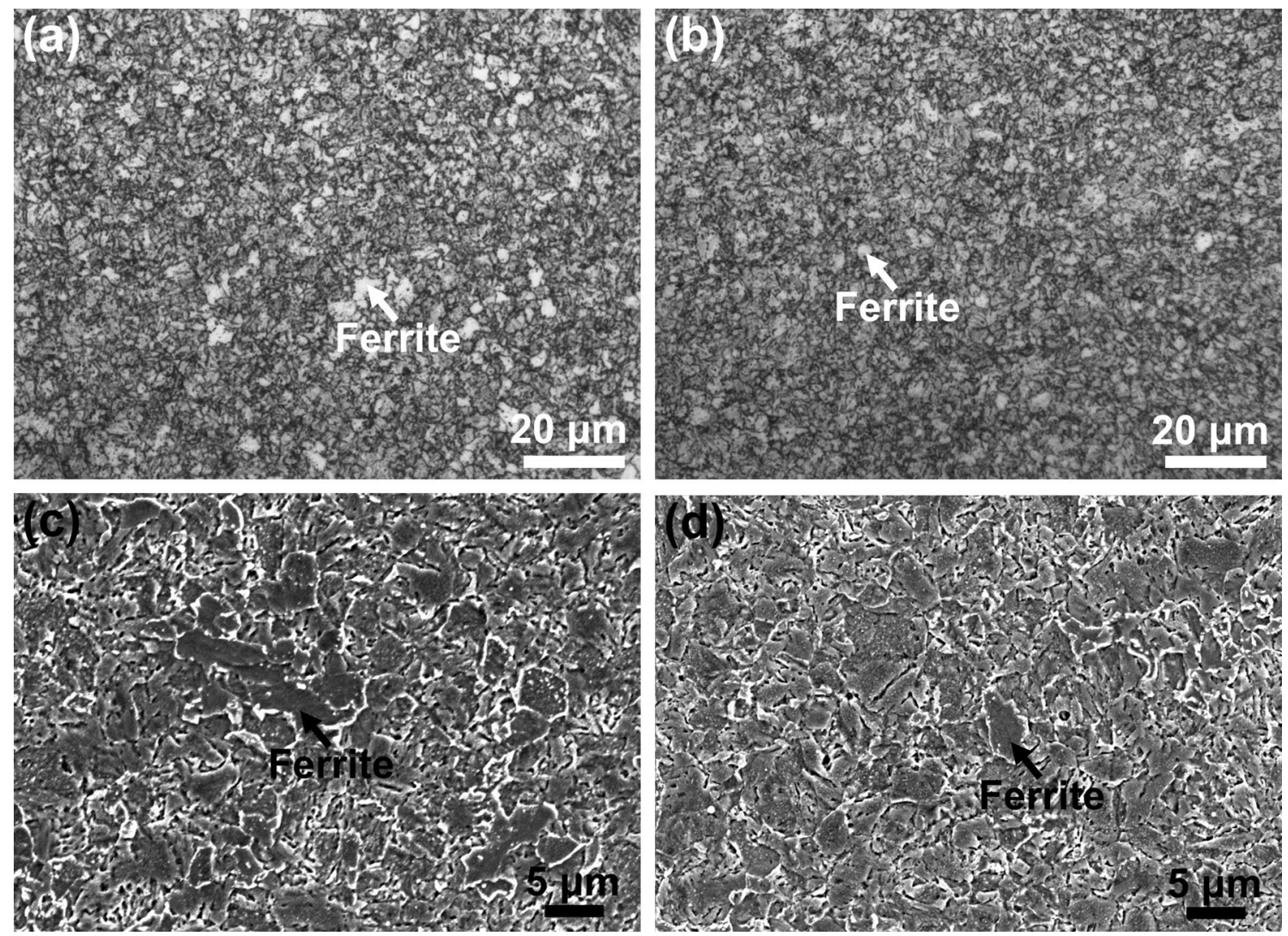

Fig. $11 \mathrm{OM}$ and SEM micrographs of as-annealed 9Cr-ODS steels subjected to isothermal treatment at a, $\mathbf{c} 870{ }^{\circ} \mathrm{C}, \mathbf{b}, \mathbf{d} 1000{ }^{\circ} \mathrm{C}$

for diffusionless shear reverse transformation is larger as carbon is soluted in martensite matrix, the reverse transformation mechanism changes from diffusionless to diffusive for carbon-added $\mathrm{Fe}-\mathrm{Cr}-\mathrm{Ni}$ alloys [24, 25]. The reverted austenite can nucleate at lath boundaries, prior austenite grain boundaries or within prior austenite grains. The most likely nucleation site inside the grain is the carbide particle [26].

With respect to the sintered ODS steels, the reverted transformation from martensite to austenite should be diffusion-controlled, considering the carbon in martensite and slow heating rates in this work. The driving force for the austenite transformation can be originated from the changes in chemical energy and the stored strain energy. The heating rates can affect the release of stored strain energy prior to austenite formation. As the heating rate is slow, more strain energy is consumed before the austenite starts to nucleate, and less strain energy could be provided to driving force. The residual ferrite is closely related to the competence between the driving force of austenite transformation and the pinning effects of oxide nanoparticles on austenite/martensite interface. Assuming the pinning force of oxides on the interface is almost the same under various heating rates, the amount and size of residual ferrite are then dependent on the driving force of austenite transformation.
With increasing heating rate, the driving force of austenite transformation is increased, leading to the decrease in both the amount and size of residual ferrite. As isothermal heat treatment is performed above $\mathrm{Ac}_{1}$, the lower isothermal temperature will promote more release of strain energy. Thus, compared with the ferrite distribution obtained in continuous heating, the low holding temperature in isothermal treatment will change the ferrite distribution significantly.

For the annealed ODS steels, the $M_{23} \mathrm{C}_{6}$ contains certain amount of carbon. Thus, the dissolution of $M_{23} \mathrm{C}_{6}$ is crucial to the austenite transformation, since carbon is a strong austenite stabilizer. The Thermo-Calc software predicts that the dissolution of $M_{23} \mathrm{C}_{6}$ carbides occurs at temperatures above $900{ }^{\circ} \mathrm{C}$ [27]. Slow heating rate will promote the $M_{23} \mathrm{C}_{6}$ dissolution, increasing the driving force for austenite formation. The $\alpha / \gamma$ interface will advance into the ferrite, decreasing the amount and size of residual ferrite. In isothermal treatment, higher isothermal temperature will promote more $M_{23} \mathrm{C}_{6}$ to be dissolved, and have larger effect on the ferrite distribution.

For the same heating rate, both $\mathrm{A}_{\mathrm{c} 1}$ and $\mathrm{A}_{\mathrm{c} 3}$ of sintered ODS steels are close to those of annealed ODS steels, indicating that the driving forces for austenite transformation of these two steels are close. As the heating rate increases from 
10 to $40{ }^{\circ} \mathrm{C} / \mathrm{min}$, the temperature difference between $\mathrm{A}_{\mathrm{cl}}$ and $\mathrm{A}_{\mathrm{c} 3}$ of sintered ODS steels is, respectively, $52{ }^{\circ} \mathrm{C}, 63{ }^{\circ} \mathrm{C}$, $67^{\circ} \mathrm{C}$ and $79^{\circ} \mathrm{C}$, while the temperature difference between $\mathrm{A}_{\mathrm{c} 1}$ and $\mathrm{A}_{\mathrm{c} 3}$ of annealed ODS steels is, respectively, $50{ }^{\circ} \mathrm{C}$, $73{ }^{\circ} \mathrm{C}, 79^{\circ} \mathrm{C}$ and $81{ }^{\circ} \mathrm{C}$. The kinetics of austenite transformation in annealed ODS steels is slightly slower than that in sintered ODS steels, except for $10^{\circ} \mathrm{C} / \mathrm{min}$. The carbon content in ferrite, $\mathrm{Cr}_{23} \mathrm{C}_{6}$ and austenite is, respectively, 0.02 $\mathrm{wt} \%, 5.68 \mathrm{wt} \%$ and $0.1 \mathrm{wt} \%$. Large composition fluctuation is readily produced between ferrite and $\mathrm{Cr}_{23} \mathrm{C}_{6}$, facilitating the austenite nucleation. On the other hand, since the carbide dissolution requires a certain time, thus, at higher heating rate, the austenite transformation of annealed ODS steels requires longer time to complete.

\section{Conclusions}

By DSC measurements, the austenite transformation behaviors of ODS steels with different initial microstructures are investigated. Novel ways to control the residual ferrite in ODS steels are proposed. The main conclusions can be summarized as follows:

1. With increasing heating rate, both $\mathrm{Ac}_{1}$ and $\mathrm{Ac}_{3}$ of ODS steels shift to high temperature range, irrespective of the initial microstructures.

2. The residual ferrite in ODS steels can be tailored by continuous heating of ODS steels with different microstructure characteristics. For the sintered ODS steels, with increasing heating rate, both the amount and size of residual ferrite will be decreased. For the annealed steels, the amount and size of residual ferrite will be increased as the heating rate increases.

3. The isothermal treatment above $\mathrm{Ac}_{1}$ can also affect the ferrite distribution in ODS steels. For the sintered ODS steels, lower isothermal temperature has a more evident effect on the changes in ferrite distribution, while this is contrary for the annealed ODS steels.

Acknowledgements This work was financially supported by the National Natural Science Foundation of China (No. 52034004) and the China Postdoctoral Science Foundation Grant (No. 2019M650028).

\section{References}

[1] G.R. Odette, M.J. Alinger, B.D. Wirth, Annu. Rev. Mater. Res. 38, 471 (2008)

[2] S. Ukai, M. Fujiwara, J. Nucl. Mater. 307-311, 749 (2002)

[3] C.A. Williams, P. Unifantowicz, N. Baluc, G.D.W. Smith, E.A. Marquis, Acta Mater. 61, 2219 (2013)

[4] D. Pazos, M. Suárez, A. Fernández, P. Fernández, I. Iturriza, N. Ordás, Fusion Eng. Des. 146, 2328 (2019)

[5] C.P. Massey, S.N. Dryepondt, P.D. Edmondson, K.A. Terrani, S.J. Zinkle, J. Nucl. Mater. 512, 227 (2018)

[6] S. Yang, J. Chen, H. Fu, P. Wang, Z. Zhou, P. Zheng, Fusion Eng. Des. 151, 111406 (2020)

[7] S.M.S. Aghamiri, T. Sowa, S. Ukai, N. Oono, K. Sakamoto, S. Yamashita, Mater. Sci. Eng. A 771, 138636 (2020)

[8] J. Fu, J.C. Brouwer, R.W.A. Hendrikx, I.M. Richardson, M.J.M. Hermans, Mater. Sci. Eng. A 770, 138568 (2020)

[9] S. Xu, F. Long, S.Y. Persaud, N. Guo, Z. Yao, M.R. Daymond, W. Gao, L. Zhang, Z. Zhou, Corros. Sci. 165, 108380 (2020)

[10] S. Ukai, Y. Kudo, X. Wu, N. Oono, S. Hayashi, S. Ohtsuka, T. Kaito, J. Nucl. Mater. 455, 700 (2014)

[11] H. Zhao, T. Liu, Z. Bai, L. Wang, W. Gao, L. Zhang, Corros. Sci. 163, 108272 (2020)

[12] M.S. El-Genk, J.M. Tournier, J. Nucl. Mater. 340, 93 (2005)

[13] M. Yamamoto, S. Ukai, S. Hayashi, T. Kaito, S. Ohtsuka, Mater. Sci. Eng. A 527, 4418 (2010)

[14] A. Das, P. Chekhonin, E. Altstadt, D. McClintock, F. Bergner, C. Heintze, R. Lindau, J. Nucl. Mater. 542, 152464 (2020)

[15] R. Miyata, S. Ukai, X. Wu, N. Oono, S. Hayashi, S. Ohtsuka, T. Kaito, J. Nucl. Mater. 442, 138 (2013)

[16] S. Ukai, S. Ohtsuka, Energy Mater. 2, 26 (2007)

[17] S. Ukai, S. Ohtsuka, T. Kaito, H. Sakasegawa, N. Chikata, S. Hayashi, S. Ohnuki, Mater. Sci. Eng. A 510-511, 115 (2009)

[18] M. Yamamoto, S. Ukai, S. Hayashi, T. Kaito, S. Ohtsuka, J. Nucl. Mater. 417, 237 (2011)

[19] X. Wu, S. Ukai, N. Oono, S. Hayashi, S. Shi, S. Chen, H. Sakasegawa, H. Tanigawa, J. Nucl. Mater. 452, 212 (2014)

[20] H. Oka, T. Tanno, S. Ohtsuka, Y. Yano, T. Kaito, Nucl. Mater. Energy 16, 230 (2018)

[21] S. Ohtsuka, S. Ukai, M. Fujiwara, J. Nucl. Mater. 351, 241 (2006)

[22] H. Oka, T. Tanno, S. Ohtsuka, Y. Yano, T. Uwaba, T. Kaito, M. Ohnuma, Nucl. Mater. Energy 9, 346 (2016)

[23] X. Zhou, Y. Liu, L. Yu, Z. Ma, Q. Guo, Y. Huang, H. Li, Mater. Des. 132, 158 (2017)

[24] C.A. Apple, G. Krauss, Acta Metall. 20, 849 (1972)

[25] S.J. Lee, Y.M. Park, Y.K. Lee, Mater. Sci. Eng. A 515, 32 (2009)

[26] Y. Tomota, W. Gong, S. Harjo, T. Shinozaki, Scr. Mater. 133, 79 (2017)

[27] K.D. Zilnyk, V.B. Oliveira, H.R.Z. Sandim, A. Möslang, D. Raabe, J. Nucl. Mater. 462, 360 (2015) 